\title{
A Dilemma in Tycoon Food Company
}

\author{
Dr. Neema Gupta, Graphic Era University, India.
}

\author{
Mr. Asharuddin, IMS Roorkee, India.
}

Abstract: Branch manager of a Tycoon Food Company receives a call from his head office, asking him to suggest a name of eligible candidate, whom they can promote as a branch head of newly established branch. Mr. Chadda, a branch manager, shortlisted two candidates: Mr. Manoj and Mr. Rakesh. Mr. Manoj a self driven person and usually follows autocratic leadership style. Mr. Rakesh is friendly and fun loving in nature. Both persons are doing well in their jobs. Now it's a dilemma for a branch manager, to whom he would recommend for the post of branch manager of new branch.

Keywords: Autocratic style, Branch manager, Tycoon Food Company.

\section{CASE}

Mr. Chadda, a branch manager, of Tycoon Food Company, receives a call from his head office, asking him to recommend one of his eligible subordinate as branch manager of a newly opening branch in nearby town. After considering all the details of eligible employees, he shortlisted two candidates name Mr. Manoj Kashyap and Mr. Rakesh Singh. Mr Manoj is a self driven person who has an experience of 12 years and always performed as per agreed KRA Parameters. He handles a team of 9 people and usually follows an autocratic leadership style to lead his team vigorously for achieving targets. He along with his team never missed any target in his full career. He expect from his employees to strictly follow the instruction given by him. He is usually heard, shouting at his subordinates in the office. But he and his team has a record of earning highest sales incentives year after year. His team usually seems to be under work pressure. Mr. Rakesh, on the other hand, is also a very energetic and young manager, having more or less same experience as Mr. Manoj. Mr. Rakesh, as a leader, is fun loving and friendly in nature. He has 10 years experience in sales and handles a team of 12 people. He believes in participative style of leadership to drive people working under him. He invites his subordinates to participate in decision making process, whenever it is required. His subordinates enjoy their work while working under his supervision and they always give their best to their leader. He sometimes takes his team out for lunch and believes in motivating team members by praising them in public. He achieves all his targets given by his superiors. He is very good in engaging his team members for collective team work. Both persons are doing well in their jobs. Now it's a dilemma for a branch manager, to whom he would recommend for the post of branch manager of new branch.

\section{PROBLEMS OF THE CASE}

1- Dilemma of a branch manager to recommend the name of one of them for branch manager of new branch in nearby town.

2- The branch manager, though is the main decision maker in the branch, considers both as eligible candidate for the post of branch head. Because every time a manager can't use either one of the styles as a leadership style to lead people. Both leadership styles are required to get the work done through people. Mr. Manoj and Mr. Rakesh, though both having different approach but giving more or less the same results. So this situation has put the Branch manager in dilemma.

3- If he recommends the name of anyone, the other would definitely raise the question of not recommending his name.

4- The problem of a branch manager is how to handle the feelings of other one to whom he would not recommend.

\section{ASSIGNMENT QUESTIONS}

Q1. If you are the branch manager of the branch how would you view the perspective of both the candidates having intention to become a branch manager?

Q2. If you are the branch manager of the branch to whom you would recommend for the post of branch manager and why?

Q3. If you select Mr. Rakesh, as a branch manager, how would you handle the feelings of Mr. Manoj of not being recommended?

\section{IV.SUGGESTED ANSWERS}

Ans1. If I were the branch manager of the branch, I would be having the same perspective as of both candidates because there are number of benefits to the candidates associated with the post of branch head like, higher level, advancement in the career, higher salary, opportunities to learn new skills, challenging job, new task, handling a 
team of a large number of people with heterogeneous personalities, etc.

Ans2. Being a branch head, I would recommend Mr. Rakesh as a branch head for a newly established branch. There are a number of reasons of promoting him as a branch head:

i- $\quad$ A good leader always gives freedom to his employees to give suggestions and ideas in decision making process.

ii- He trusts his team members and give them opportunities to learn to handle the complex task.

iii- A good leader always believes in inculcating leadership skills in his subordinates.

iv- Subordinates working under a leader, having participative leadership styles, feel free to discuss the problems. A participative leader develops a feeling of sense of belongingness among all the subordinates working under him. The feeling of sense of belongingness makes his subordinates realise that they are the important assets of the organization. It develops a feeling of ownership.

v- A good leader builds a healthy relationship and good working environment.

The qualities which I discussed above, are the qualities of a branch head. Mr. Rakesh, being a participative leader possesses all the qualities. That is why, I would recommend Mr. Rakesh as a branch head for the new branch.

Ans3. If I select Mr. Rakesh as a branch head, Mr. Manoj would definitely approach me. I will make him understand that only achievement of target is not enough to get a promotion at higher level. We, as a leader, should also understand the feelings of our subordinates. Instead of treating them as a factor of production, a leader should always treat his employees as human beings. I will also make him understand that you are a very task oriented person but not a good leader. Every time we can't exercise autocratic leadership styles over the subordinates. In this style, the subordinates stop using their mind and only follow the instructions given by a leader. I will also tell him that subordinates working under autocratic leadership styles, only become followers not the leader in future. Because they don't get freedom to feel free and their ideas are not entertained by a leader. I would also tell him that a branch manager needs all those qualities which I discussed in answer two. I will tell him that if you inculcate the qualities of a branch head like understanding people and their problems, developing healthy relationship, giving freedom to the employees to give ideas, developing a sense of belongingness among them etc, I would definitely recommend your name next time.

\section{TEACHING NOTES}

\section{A. SUMMARY OF THE CASE}

Tycoon food company is planning to establish a new branch in nearby cities. For this company needs a dynamic and result oriented personality for the post of branch manager, who can handle the higher responsibilities. When branch manager Mr. Chadda was asked to recommend the name of person to whom the company can make him the branch manager of new branch. After analysis, Mr. Chadda came out with two names Mr. Manoj having autocratic type of leadership style, where the subordinates are having a feeling of punishment if not being performed well and Mr. Rakesh, following participative leadership style where people enjoy their work. The result of both the leaders is more or less same. Dilemma of Mr. Chadda is to whom he would recommend as a branch head for the new branch.

\section{B. TEACHING OBJECTIVES}

1. To enable the learner to equip with the HR issues related to the HR systems and policies working in the corporate premises.

2. To enable the learner about real time hands-onexperience off the job.

3. To enable the learner to apply the appropriate tactics to deal with day to day HR issues in the company.

C. MAJOR ISSUES IN THE CASE

1. Both the leaders are task oriented and giving their best in the company.

2. Both are eligible candidates for the promotion.

3. Both have more or less same experience and giving good performance to the company.

4. Dilemma of Mr. Chadda is to whom he would recommend for the post of Branch Head.

\section{PEDAGOGICAL REVIEW}

Individual case reading: 15 minutes

Group discussion of the case: 15 minutes

Case presentation: 10 minutes 